\title{
Substitution of wheat bran by cassava flour in the diet: effect on the growth of chickens
}

\author{
Beugré Grah Avit Maxwell ${ }^{1}$, Gbogouri Grodji Albarin², Kimsé Moussa ${ }^{3}$, Gnakri Dago' \\ ${ }^{1}$ Laboratoire de Nutrition et de Sécurité Alimentaire, U.F.R. des Sciences et Technologie des Aliments, Université Nangui Abrogoua, 02 \\ BP 801 Abidjan 02, Côte d'Ivoire \\ ${ }^{2}$ Laboratoire de Biochimie et de Microbiologie, Université Jean Lorougnon Guedé, BP 150 Daloa, Côte d'Ivoire \\ ${ }^{3}$ Laboratoire de Biologie et de Cytologie Animale, UFR des Sciences de la Nature, Université Nangui Abrogoua, 02 BP 801 Abidjan 02 , \\ Côte d'Ivoire
}

\section{Email address:}

maxwellfrb@yahoo.fr (B. G. A. Maxwell)

\section{To cite this article:}

Beugré Grah Avit Maxwell, Gbogouri Grodji Albarin, Kimsé Moussa, Gnakri Dago. Substitution of Wheat Bran by Cassava Flour in the Diet: Effect on the Growth of Chickens. Agriculture, Forestry and Fisheries. Vol. 3, No. 1, 2014, pp. 6-12.

doi: 10.11648/j.aff.20140301.12

\begin{abstract}
Chicken diet cost represents up to $70 \%$ of the production charges. Inputs, which are mostly imported products such as lysine, methionine, wheat bran are the cause of the expensive cost of foods. Wheat bran is not available in Côte d'Ivoire and could be efficiently substituted by cassava. Cassava is affordable and available all year round. The objective of this work was to determine the effects of the substitution of wheat bran by cassava flour on the growth of chickens. After administering ad libitum during 8 weeks the different food categories (starting and growing food), results showed that protein, fat, ash and calcium contents improved more with the addition of cassava for both starting and growing periods. The energy value of cassava-based feed was higher than that of foods containing wheat bran: $12155 \mathrm{~kJ} / \mathrm{kg}$ against 11428 $\mathrm{kJ} / \mathrm{kg}$ for the starting food and $12586 \mathrm{~kJ} / \mathrm{kg}$ against $11577 \mathrm{~kJ} / \mathrm{kg}$ for growth, respectively. Throughout the rearing period, the growth of chicken fed with the cassava-based diet was much higher than that of the chicken fed with the control diet. In the growing food, palmitic acid was the dominant saturated fatty acids with the cassava-based diet exhibiting higher values of saturated fatty acids. The content of unsaturated fatty acids from cassava (48.6\%) was slightly higher than the control diet (47.6 \%). Except magnesium, macro-element concentrations were higher in the cassava-based diet than those of food control. Micronutrients such as manganese and zinc had a high value in cassava-based diet than the control diet. Hydrogen cyanide which is in the fresh pulp at $100 \mathrm{mg} / \mathrm{kg}$, decreased at $1.8 \mathrm{mg} / \mathrm{kg}$ of dry matter in the start food and at $1.9 \mathrm{mg} / \mathrm{kg}$ of dry matter in the growth food. The substitution of wheat by cassava improves feed nutritional profile, also reduces the production cost, food industry will benefit from this up to $13,36 \%$ in start-up period and up to 13 , $25 \%$ in growing period.
\end{abstract}

Keywords: Cassava, Growth, Hydrogen Cyanide, Substitution

\section{Introduction}

One of the major challenges of the Ivory Coast is to obtain and ensure food production for a growing population. This food production will be achieved through the enhancement of agricultural products, including livestock. That concern led the government to initiate in 1972 a vigorous policy of food self-sufficiency. That policy focused on short-term livestock-based [1].

The broiler of intensive and egg production have very quickly had the support of farm operators to the point that in 2000, Ivory Coast produced 22841 tons of meat and
41,19 tons of eggs covering $80 \%$ and $100 \%$ of the national consumption of meat and eggs, respectively [2]. However, the cost of chickens feed alone accounts for $70 \%$ of the costs of production [3, 4].

Inputs, which are mostly imported products such as lysine, methionine, wheat bran are the cause of the expensive cost of foods [5]. If we substitute these inputs for local products, we will bring down production costs. Wheat bran, a by-product of imported wheat is not available throughout the country. It may well be replaced by cassava, which has apparently equivalent energy, is cheaper and easily accessible anywhere any season $[6,7]$. 
The objective of this work was to determine the effect of the substitution of wheat bran by cassava flour.

\section{Material and Methods}

\subsection{Animals}

For the study, we had 350 chicks, Hubbard strain, aged 1 day and weighing $42 \pm 1 \mathrm{~g}$, purchased from FOANI company (Abidjan), 350 traditional breeding chicks from the Sahel countries and from the forest of Ivory Coast, conventionally called African chicks and baptised saiguèSissè.

\subsection{Poultry Diets}

The composition of start-up and growth food used in this study is recorded in Tables 1 and 2. Chicks received food and drinking water ad libitum, in feeders and drinking trough every day according to the method of $[8,9]$. The food of start-up (Table 1) was fed to chicks during the first 3 weeks of rearing while; the food for growth (Table 2) was administered to chickens after 3 weeks to, significantly, increase the energy.

\subsection{Measurements}

\subsubsection{Weighing Poultry}

The chicks were weighed using an electronic balance before feeding. They were then weighed weekly, at the same time $(9 \mathrm{~h})$, throughout the period of breeding.

\subsection{Feeding}

During the 8 weeks of rearing, rations were weighed and remnant feed are evaluated.

\subsection{Study of Nutritional and Energy Values of Formulated Food}

Amino acids content was analysed using the method of liquid chromatograph type BECKMAN 420 coupled with an integrator CR3A SHIMADZU [10]. Starch content was determined using the modified technique of Mc Cready [11], Moisture was determined gravimetrically after drying sample overnight at $105{ }^{\circ} \mathrm{C}$. Lipid content was determined using the method of soxhlet [12, 13], fatty acids content was quantified using gas chromatography method [14, 15]. Ash was quantified after incinerating the sample in the muffle furnace at $550{ }^{\circ} \mathrm{C}$ overnight and minerals (potassium, phosphorus, iron, manganese sodium, calcium, magnesium, zinc, copper and silica) were analysed by atomic absorption spectrophotometry (Perkin Elmer, Model 1100, Paris, France). The following method used by Young $\mathrm{G}$ [16]. Soluble sugars content was determined through the method described by Ashwell M and A Diplock [17]. Hydrogen cyanide content was determined using the method of Food and Agriculture Organisation, Metabolizable energy was calculated using the technique indicated by BIPEA [18].

\subsection{Production Cost of the Food}

The prices of raw materials were collected in several markets of Ivory Coast: the region of "Bas-Sassandra", the region of Lagoons and the region of "Agneby". Prices were collected from 10 markets in each region, a total of 30 markets.

\subsection{Statistical Analysis}

Statistical techniques were used to analyse the results [19]. Results are expressed as the mean \pm standard deviation of several values of samples with Kyplot (version 2.0 beta 15, (C1997- 2001, Koichi Yoshioka) statistical software. The data were statistically analyzed by one way analysis of variance (ANOVA). Means were compared by Turkey's test. Differences were considered statistically significant at $* \mathrm{P}<0.05$. All measures were done in triplicate.

\section{Results}

\subsection{Nutritional and Energy Value of Diets}

\subsubsection{Chemical Composition and Energy Value of Diets}

The chemical composition and energy of the control diet (wheat-based) and the cassava-based feed are shown in Tables 3 and 4.

Rates of protein, fat and ash of the cassava-based foods improved more compared to those of control foods both for the start-up and for the growing period:

In the start-up food, the difference in the nutrients content reached to $1 \%$ for protein and cellulose, this difference was about more than $2 \%$ concerning fatty matter, for the others nutrients, values were more or less close.

In the growth food, the differences were noted only for protein, cellulose and fatty matter (value close to $1 \%$ ).

Three nutrients drawn differences between food in this two periods of life. Energy value was higher in the cassava feeds $[12155 \pm 8 \mathrm{~kJ} / \mathrm{kg}$ and $12586 \pm 18 \mathrm{~kJ} / \mathrm{kg}]$ compared to, the control diet $\left[\begin{array}{lll}11 & 428 \pm 9 \mathrm{~kJ} / \mathrm{kg} \text { and } 11577\end{array}\right.$ $\pm 129 \mathrm{~kJ} / \mathrm{kg}]$.

\subsection{Amino Acid Content of Diets}

The amino acid composition of the control diet and substituted diet based cassava are shown in Tables 5 and 6 .

Fourteen amino acids were identified including 7 essential amino acids (Tables 5 and 6) which are noted with an asterisk (*). Alanine, aspartic acid and methionine contents were higher in the wheat bran based starter diet than in the new cassava-based starter diet.

At the same time in the growth phase, the levels of these amino acids were high in the control diet (Table 6). However, the substituted diet based cassava appeared rich in essential amino acids.

\subsection{Fatty Acid Content of Diets}

The fatty acid content of diet fat are shown in tables 7 
and 8 into two broad classes:

- four saturated fatty acids : lauric acid (C12: 0), myristic acid (C14: 0), palmitic acid (C16: 0) and stearic acid (C18: $0)$;

- two unsaturated fatty acids, including oleic acid (C18: 1n9) and one polyunsaturated fatty acid: linoleic acid (C18: 2n6).

Saturated fatty acids in the start-up food were strongly dominated by palmitic acid (between 30 and $45 \%$ ) in both control and cassava based diet. Unsaturated fatty acids in the start-up food of cassava had a higher amount (48.9\%) than the control diet based wheat $(38.5 \%)$ in the same phase. Meanwhile, in the growing food, palmitic acid was the dominant saturated fatty acid. The content of unsaturated fatty acids from cassava (48.6\%) was slightly higher than the control diet $(47.6 \%)$.

\subsection{Mineral Content of Diets}

There are major elements and micronutrients in the diets (see Tables 9 and 10). Macro-elements, with the exception of magnesium, were higher in the cassava based diet than those in the food control. Cobalt and silica, with a weak value in the food, had identical values $(10 \pm 1 \mathrm{~g} / \mathrm{kg})$.
Micronutrients such as manganese and zinc had a high value in cassava based diet around 300 and $400 \mathrm{mg} / \mathrm{kg}$ as a difference between starting food and growing food respectively.

\subsection{Hydrogen Cyanide in the Diets}

Hydrogen cyanide rate in cassava based diet is shown in Table 11. That presence was respectively of $1.8 \pm 0.2 \mathrm{mg} /$ $\mathrm{kg}$ in the start-up food and $1.9 \pm 0.1 \mathrm{mg} / \mathrm{kg}$ in food for growth.

\subsection{Growth Performance of Food}

Figures 1 and 2 shows the body growth curves of the broiler and african chicken fed with the two types of foods. Throughout the rearing period, the growth of chicken fed with the cassava-based diet was much higher. In eight weeks, broilers fed with the cassava-based diet weight 1882 $\pm 12 \mathrm{~g}$, while the broiler fed with the control diet, weight $1730 \pm 15 \mathrm{~g}$.

African chicken were heavier on cassava based diet $(890$ $\pm 11 \mathrm{~g})$ than on wheat bran $\operatorname{diet}(796 \pm 9 \mathrm{~g})$

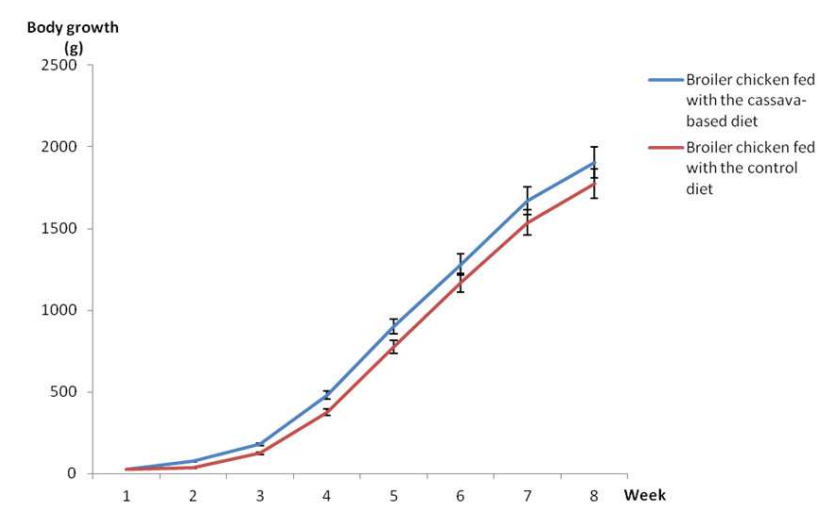

Figure 1. Growth in weight of broiler chicken submitted to the control diet and cassava-based diet.

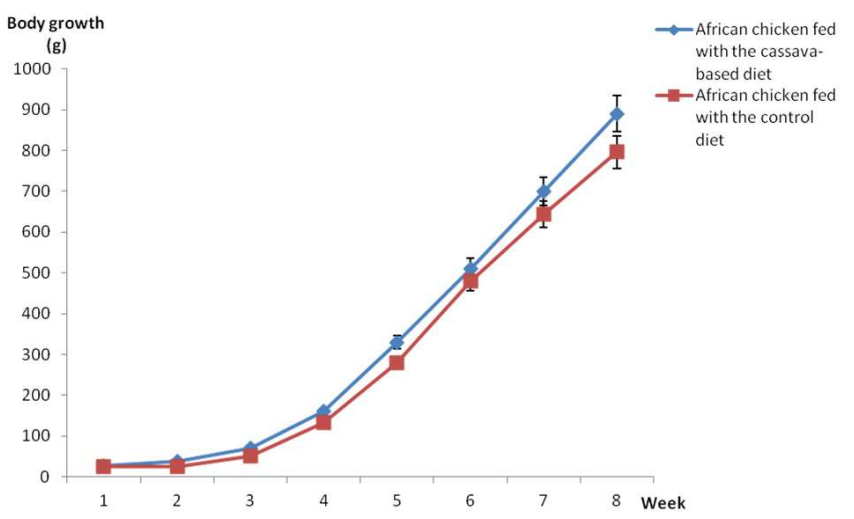

Figure 2. Growth in weight of African chicken submitted to the control diet and cassava-based diet.

\subsection{Production Cost of the Diet}

Table 12 present the production costs of starting foods: the control diet based on the wheat (industrial type) and the cassava-based diet.
The control diet (industrial type) cost is up to $152350 \mathrm{~F}$ CFA per tonne, while the cost of the food start-up food of cassava amounted to $132050 \mathrm{~F}$ CFA per tonne, a difference of 20300 F CFA, representing $13.36 \%$ discount.

The growing food for its part is up to $145250 \mathrm{~F}$ CFA per 
tonne for the blank feed against

$126900 \mathrm{~F}$ CFA for food made of cassava, a difference of 18350 F CFA representing $13.25 \%$ cost reduction.

\subsection{Health Status of Chickens}

The health status of chickens subjected to the experiment was generally acceptable. The cumulative mortality rate for both tests is reported in Table 13. The mortality rate for birds on the control diet (industrial) and the cassava food vary between $3 \%$ and $6 \%$ :

- with the control diet, the mortality rate of African chicken is $4 \%$, while the broiler is $6 \%$;

- for food made of cassava, the mortality rate for African chicken is $3 \%$, with $6 \%$ for the broiler.

\section{Discussion}

Mortality rates of birds during the study period are very low. These rates are well below the $10 \%$ limit recommended by [20]. These results could be explained by the good nutritional characteristics offered by the food given to animals. Indeed the food must provide some energy, the plastic elements and factors operating to maintain life [21].

Also, the elimination of hydrogen cyanide cassava by means of various treatments makes the cassava food safe for consumption $[22,23]$.

Thus, the weight gain of chickens fed with different diets based on cassava and chickens subject to the control diet show a significant difference both in the two phases: the start-up and the growth.

Diets of starting and growing at $20 \%$ incorporation of cassava have advantages compared to the control. Indeed, both the broiler chicken and the African chicken type, the curve of chicken fed with the diet containing cassava is above that of chicken fed with the control diet.

This rapid growth of chicken fed with the cassava food is due to the energy brought by cassava and element supplied by the palm oil and soybean meal. Energy needs taking precedence over all other material requirements, any deficiency leads necessarily to a limitation of plastics and other needs regulators [24].

Soybean meal is important because of its richness in essential amino acids including lysine [25]. Also, it should be noted that palm oil is characterized by its high content of palmitic acid and energy [26]. It is well known that carbohydrate and fat provide energy. But in this growth process, the unsaturated fatty acids, including linoleic acid, play an essential role in body weight gain by acting preferentially in the fortifications of the body. So his absence leads a general weakness [27, 28].

It should be noted that the cassava based diet provides better benefits to the animals. Compared to the control diet (based on the wheat), the cassava based diet is cheaper. This difference in the production cost is greater with the start up food. The low cost of the cassava based diet compared to the control diet was due to the low price of cassava tuberous roots. The incorporation of cassava, however, prompted the provision of certain raw materials, namely palm oil, soybean meal and copra. These raw materials have led to the adequacy of nutritional needs and cost.

With the contributions of soybean meal, the protein is relatively higher in the control diet. It is the same energy that would result from supplementation of the meal, coconut, oil palm and even cassava flour.

\section{Conclusion}

Concerning nutritional and energy value of diets, protein, cellulose and fatty matter drew differences between food types in the starting up as in the growth period. The energy value is higher for food based on cassava. Also the substituted diet based cassava was rich in essential amino acids, oligo-elements. Fed with the cassava-based diet induces a gain of weight for the two types of chicks. It is easy to conclude that the food based on cassava is a good option for contents and energy. In more, food based on cassava reduces the production cost by $15 \%$ in start-up and $18 \%$ in growing feeding period of chickens. The effects of food based on cassava were positives about contents, energy and costs. The substitution of wheat by cassava is a productive option. This option could be improve and become one of the best solutions to breed chickens in guaranties.

Table 1. Composition of diets for poultry. Source : [9]

\begin{tabular}{lll}
\hline Ingredient & Starting food $(\mathbf{g} / \mathbf{1 0 0 g})$ & Growing food(g/100g) \\
\hline Maize & 59 & 59 \\
Wheat bran & 14 & 16 \\
Cottonseed meal & 13 & 13 \\
Fishmeal & 12.45 & 10.45 \\
Shell & 1 & 1 \\
Salt & 0.3 & 0.3 \\
Vitamin complex* & 0.15 & 0.15 \\
Lysine & 0.05 & 0.05 \\
Methionine & 0.05 & 0.05 \\
\hline
\end{tabular}

Table 2. Composition of diets substituted cassava

\begin{tabular}{lll}
\hline Ingredients & Starting food $(\mathbf{g} / \mathbf{1 0 0 g})$ & Growing food $\mathbf{( g / \mathbf { 1 0 0 g } )}$ \\
\hline Maize & 39 & 39 \\
Cassava & 20 & 20 \\
Copra meal & 1.5 & 1.45 \\
Cotton seed meal & 13 & 14 \\
Soy bean meal & 13.45 & 14 \\
Crude palm oil & 1.5 & 2 \\
Fishmeal & 10 & 8 \\
Shell & 1 & 1 \\
Salt & 0.3 & 0.3 \\
Vitamin complex & 0.15 & 0.15 \\
Lysine & 0.05 & 0.05 \\
Methionine & 0.05 & 0.05 \\
\hline
\end{tabular}


Table 3. Chemical composition and energy value of starting foods

\begin{tabular}{lll}
\hline & Food control & Cassava-based food \\
\hline Protein (\%) & $20.01 \pm 0.7$ & $21 \pm 0.6$ \\
Starch (\%) & $42.10 \pm 2.2$ & $42.70 \pm 2.1$ \\
Sugar (\%) & $2.70 \pm 0.1$ & $2.30 \pm 0.1$ \\
Cellulose (\%) & $8.10 \pm 0.5$ & $7.20 \pm 0.4$ \\
Fatty matter (\%) & $4.28 \pm 0.2$ & $6.01 \pm 0.3$ \\
Ash (\%) & $8.90 \pm 0.7$ & $9 \pm 0.8$ \\
Metabolizable energy & $11428 \pm 9$ & $12155 \pm 8$ \\
(kilojoules /kg) & & \\
\hline
\end{tabular}

Table 4. Chemical composition and energy value of growth food

\begin{tabular}{lll}
\hline & $\begin{array}{l}\text { Wheat-based food } \\
\text { (control)* }\end{array}$ & $\begin{array}{l}\text { Cassava-based } \\
\text { food* }\end{array}$ \\
\hline Protein (\%) & $19.04 \pm 0.8$ & $20.03 \pm 0.9$ \\
Starch (\%) & $43.5 \pm 3.1$ & $43.6 \pm 2.9$ \\
Sugar (\%) & $2.8 \pm 0.1$ & $2.5 \pm 0.1$ \\
Cellulose (\%) & $8.3 \pm 0.6$ & $7.7 \pm 0.5$ \\
Fatty matter (\%) & $4.3 \pm 0.2$ & $5.2 \pm 0.4$ \\
Ash (\%) & $8.5 \pm 0.5$ & $8.8 \pm 0.4$ \\
Metabolizable & $11577 \pm 12$ & $12586 \pm 18$ \\
energy $(\mathrm{KJ} / \mathrm{kg})$ & & \\
\hline
\end{tabular}

*The results are the average of 10 tests

Table 5. Amino acids content ( $\mathrm{g} / 100 \mathrm{~g}$ ) of the starting food

\begin{tabular}{lll}
\hline Amino acid & $\begin{array}{l}\text { Wheat-based food } \\
\text { (control) }\end{array}$ & $\begin{array}{l}\text { Cassava-based } \\
\text { food }\end{array}$ \\
\hline Alanine & $10.2 \pm 0.4$ & $5.4 \pm 0.3$ \\
Arginine & $5.4 \pm 0.2$ & $6.1 \pm 0.3$ \\
Aspartic acid & $6.4 \pm 0.2$ & $2.5 \pm 0.01$ \\
Glutamic acid & $1.52 \pm 0.06$ & $2.4 \pm 0.2$ \\
Glycine & $1.51 \pm 0.04$ & $3.1 \pm 0.1$ \\
Histidine & $3.7 \pm 0.1$ & $6.3 \pm 0.1$ \\
Isoleucine * & $8.1 \pm 0.1$ & $8.8 \pm 0.5$ \\
Leucine * & $10.2 \pm 0.7$ & $12.8 \pm 0.8$ \\
Lysine * & $4.4 \pm 0.5$ & $10.1 \pm 0.3$ \\
Methionine * & $3.20 \pm 0.1$ & $1.92 \pm 0.02$ \\
Phenylalanine+tyrosine* & $10.2 \pm 1$ & $13.8 \pm 1.3$ \\
Serine & $1.52 \pm 0.08$ & $2.2 \pm 0.5$ \\
Threonine * & $1.64 \pm 0.02$ & $5.03 \pm 0.44$ \\
Valine * & $6.5 \pm 0,3$ & $8.6 \pm 0.4$ \\
\hline
\end{tabular}

Amino acids marked (*) are essential amino acids

The results are the average of 10 tests

Table 6. Amino acids content ( $\mathrm{g} / 100 \mathrm{~g}$ ) of the growing food

\begin{tabular}{lll}
\hline Amino acid & $\begin{array}{l}\text { Wheat-based } \\
\text { (control) }\end{array}$ & $\begin{array}{c}\text { food } \\
\text { Cassava-based } \\
\text { food }\end{array}$ \\
\hline Alanine & $9.4 \pm 0.7$ & $3.8 \pm 0.3$ \\
Arginine & $5.7 \pm 0.2$ & $7.5 \pm 0,4$ \\
Aspartic acid & $6.8 \pm 0.3$ & $2.07 \pm 0.01$ \\
Glutamic acid & $1.62 \pm 0.08$ & $2.71 \pm 0.02$ \\
Glycine & $2.23 \pm 0.05$ & $4.52 \pm 0.07$ \\
Histidine & $4.14 \pm 0.11$ & $5.52 \pm 0.12$ \\
Isoleucine $*$ & $7.8 \pm 0.1$ & $9.2 \pm 0.7$ \\
Leucine & $9.40 \pm 0.2$ & $13.4 \pm 0.2$ \\
Lysine $*$ & $4.7 \pm 0.5$ & $9.4 \pm 0.7$ \\
Methionine * & $4.2 \pm 0.2$ & $2.02 \pm 0.04$ \\
Phenylalanine+tyrosine* & $10.17 \pm 0.9$ & $13.57 \pm 1.2$ \\
Serine & $2.14 \pm 0.07$ & $3.41 \pm 0.04$ \\
Threonine * & $1.11 \pm 0.03$ & $2.08 \pm 0.02$ \\
Valine * & $5.02 \pm 0.5$ & $8.4 \pm 0.2$ \\
\hline
\end{tabular}

Amino acids marked $(*)$ are essential amino acids

The results are the average of 10 tests
Table 7. Fatty acids content of the starting food

\begin{tabular}{|c|c|c|}
\hline Fatty acid & $\begin{array}{l}\text { Wheat-based food } \\
\text { (control) }\end{array}$ & Cassava-based food \\
\hline Lauric acid & $4.91 \pm 0.13$ & $1.04 \pm 0.02$ \\
\hline Myristic Acid & $3.84 \pm 0.15$ & $2.36 \pm 0.04$ \\
\hline Palmitic Acid & $43.7 \pm 3.8$ & $35.9 \pm 3.2$ \\
\hline Stearic Acid & $8.5 \pm 0.8$ & $9,7 \pm 0,3$ \\
\hline Oleic Acid & $33.1 \pm 2.4$ & $33.4 \pm 3.8$ \\
\hline Linoleic acid & $5.4 \pm 0.8$ & $15.5 \pm 2.1$ \\
\hline Saturated fatty acids & $60.95 \pm 1.5$ & $49 \pm 2.05$ \\
\hline Unsaturated fatty acid & $38.5 \pm 1$ & $48.9 \pm 1.85$ \\
\hline
\end{tabular}

The results are the average of 10 tests

Table 8. Fatty acids content of the growing food

\begin{tabular}{llll}
\hline Fatty acid & $\begin{array}{l}\text { Wheat-based } \\
\text { (control) }\end{array}$ & food & Cassava-based food \\
\hline Lauric acid & $1.88 \pm 0.01$ & $1.48 \pm 0.07$ \\
Myristic Acid & $3.74 \pm 0.05$ & $2.1 \pm 0.4$ \\
Palmitic Acid & $31.7 \pm 2.6$ & $36.7 \pm 1.8$ \\
Stearic Acid & $14.92 \pm 1.07$ & $10.9 \pm 0.8$ \\
Oleic Acid & $31.6 \pm 2.3$ & $39.2 \pm 2.7$ \\
Linoleic acid & $16.04 \pm 1.05$ & $9.4 \pm 0.4$ \\
Saturated fatty acids & $52.24 \pm 1.2$ & $51.18 \pm 1$ \\
Unsaturated fatty acid & $47.6 \pm 2$ & $48.6 \pm 1.15$ \\
\hline
\end{tabular}

The results are the average of 10 tests

Table 9. Minerals content of the starting food

\begin{tabular}{lll}
\hline & $\begin{array}{l}\text { Wheat-based food (control) } \\
\text { Macro-elements }(\boldsymbol{g} / \mathbf{k g})\end{array}$ & Cassava-based Food \\
\hline Calcium & $10.6 \pm 0.7$ & $11.9 \pm 0.5$ \\
Phosphorus & $3.3 \pm 0.5$ & $4.7 \pm 0.1$ \\
Potassium & $51.3 \pm 1.1$ & $88.2 \pm 1.5$ \\
Sodium & $1.7 \pm 0.1$ & $2.3 \pm 0.1$ \\
Magnesium & $30.3 \pm 0.9$ & $27.5 \pm 1$ \\
Silica & $0.01 \pm 0.0$ & $0,01 \pm 0,001$ \\
& Micronutrients $(\boldsymbol{m g} / \mathbf{k g})$ & \\
Iron & $8100 \pm 100$ & $7800 \pm 100$ \\
Curare & $150 \pm 10$ & $110 \pm 10$ \\
Zinc & $1400 \pm 100$ & $1700 \pm 100$ \\
Manganese & $1100 \pm 100$ & $1500 \pm 100$ \\
Cobalt & $10 \pm 1$ & $10 \pm 1$ \\
\hline
\end{tabular}

Table 10. Minerals content of the growing food

\begin{tabular}{lll}
\hline & $\begin{array}{l}\text { Wheat-based food (control) } \\
\text { Macro-elements }(\mathbf{g} / \mathbf{k g})\end{array}$ & Cassava-based Food \\
\hline Calcium & $10.7 \pm 0.9$ & $12.4 \pm 0.7$ \\
Phosphorus & $3.1 \pm 0.5$ & $4.8 \pm 0.3$ \\
Potassium & $53.1 \pm 1.1$ & $84.2 \pm 4.9$ \\
Sodium & $1.5 \pm 0.1$ & $2.4 \pm 0.1$ \\
Magnesium & $31.5 \pm 1.3$ & $23.5 \pm 1.1$ \\
Silica & $0.01 \pm 0.0$ & $0.01 \pm 0.0$ \\
& Oligo-elements $(\mathbf{m g} / \mathbf{k g})$ & \\
Iron & $8100 \pm 100$ & $7800 \pm 100$ \\
Curare & $150 \pm 10$ & $110 \pm 10$ \\
Zinc & $1400 \pm 100$ & $1700 \pm 100$ \\
Manganese & $1100 \pm 100$ & $1500 \pm 100$ \\
Cobalt & $10 \pm 1$ & $10 \pm 1$ \\
\hline
\end{tabular}


Table 11. Residual cyanide in cassava-based food

\begin{tabular}{llll}
\hline & & $\begin{array}{l}\text { Cassava- based food } \\
\text { (starting food) }\end{array}$ & $\begin{array}{l}\text { Cassava- based food } \\
\text { (growing food) }\end{array}$ \\
\hline $\begin{array}{l}\text { Residual } \\
(\mathrm{mg} / \mathrm{kg})\end{array}$ & cyanide & $1,8 \pm 0,2$ & $1,9 \pm 0,1$ \\
\hline
\end{tabular}

Table 12. Production cost of one tone of food

\begin{tabular}{lll}
\hline & \multicolumn{2}{c}{ Cost (franc CFA/Tone) } \\
& Start up & Growth \\
\hline Food control (based on wheat) & 152350 & 145250 \\
Cassava- based food & 132050 & 126900 \\
Gap & 20300 & 18350 \\
(franc CFA/Tonne) & $(13.36 \%)$ & $(13.25 \%)$ \\
\hline
\end{tabular}

Table 13. Health status of chickens

\begin{tabular}{llllll}
\hline & & \multicolumn{2}{l}{$\begin{array}{l}\text { Wheat-based } \\
\text { food (control) }\end{array}$} & $\begin{array}{l}\text { Cassava -based } \\
\text { food }\end{array}$ & \\
& $\begin{array}{l}\text { Number of } \\
\text { breeding } \\
\text { Chicken }\end{array}$ & $\begin{array}{l}\text { Chicke } \\
\text { n } \\
\text { died }\end{array}$ & $\begin{array}{l}\text { Mortalit } \\
\text { y rates } \\
(\%)\end{array}$ & $\begin{array}{l}\text { Chic } \\
\text { ken } \\
\text { died }\end{array}$ & $\begin{array}{l}\text { Mortality } \\
\text { Rates (\%) }\end{array}$ \\
\hline $\begin{array}{l}\text { African } \\
\text { Chiken }\end{array}$ & 350 & 14 & 4 & 11 & 3 \\
Broiler & 350 & 20 & 6 & 21 & 6 \\
\hline
\end{tabular}

\section{Acknowledgements}

We were grateful to the University of Nangui Abrogoua, Abidjan (Côte d'Ivoire) and his Department of Nutrition for providing the experimental sites and other facilities to undertake this study. Thanks to anonymous referees who had tremendously improved the earlier version of the manuscript.

\section{References}

[1] Akassey PR (1992) Le guide de l'agriculture en Côte d'Ivoire. Volume IV. Edition, PRAT/EUROPA, Paris 274286.

[2] Anonyme 4 (2000) Bilan des ressources animales. Editeur, DGRA. Abidjan. pp 46.

[3] Ferrando R (1969) Alimentation du poulet et de la poule pondeuse. Editeur, Vigot Frère, Paris, pp 200.

[4] Garoud R (1992) Nutrition et alimentation des animaux d'élevage. Editeur: Foucher, Paris; pp 286.

[5] Smith AJ (1992) L'élevage de la volaille. Volume. 1 Editeur : Maisonneuve et Larose, ACCT, Editeur, Paris; pp 183.

[6] Jalloh A, Dahniya MT, Gbani A B et HC Ezumah (1995) L'effet de la date d'introduction du Riz (Oryza Saliva) dans la culture du manioc (Manihot esculenta, CRANTZ) sur leur production en Sierra Leone. Institute of Agricultural Research, P.M.B.450, Freetown, Sierra Leone; p 215-221.

[7] Kraisid T (2002) Agriculture, Alimentation, Nutrition en Afrique, FAO. pp 412.

[8] Ocho AL (1998) Valorisation de la graine d'hévéa (hevea brasiliensis) : production, composition chimique de la graine et efficacité alimentaire du tourteau chez le poulet de chair et la pondeuse. Mémoire pour l'obtention du grade de Docteur $3^{\text {ème }}$ cycle. L'UFR de Biosciences de l'Université de Cocody, Côte d'Ivoire, M (811) pp 94.

[9] FAO (1977) L'Alimentation des volailles dans les pays tropicaux et subtropicaux. (Coll. F.A.O. Progrès et mise en valeur. Agriculture $n^{\circ} 82$ ). Rome, $103 \mathrm{p}$.

[10] Liaset B, Julshamm K and M Epse (2003) Chemical composition and theoretical nutrition evaluation of produced fraction from enzymatic hydrolysis of salmon frames with Protamex ${ }^{\mathrm{TM}}$. Process Biochem., 38 (12): 1747-1759.

[11] Mc Cready (1999) Sugars of citrus juices, Food technology, p 19-20.

[12] Rauscherk K, Engste R and U Freimuth (1986) Untersuchung Von Lebensmitteln Veb, Fauchbuch verlag. Leipzig, 939 p.

[13] Rosignol CA (1998) Un préliminaire important: l'extration analytique des lipides. Oléagineux, Corps Gras, Lipides, 5 (4) : 301-307.

[14] Morrisson WC (1978) Cereal lipids in "Advance in cereal science and technology », Edition Pomeranz Y. AACC. Vol II, 221-348.

[15] Uceda et Hermoso (1996) Méthodes d'analyse des matières grasses et dérivés; ETIG, Editeur, Paris - France sixième édition; $\mathrm{p} 238$.

[16] Young G (1985) Dosage de la silice par spectrophotomètre d'absorption atomique. Analytical Chemistry. NORME AFNOR N F t 90005, p.1951.

[17] Ashwell M and A Diplock (1999) Scientific concepts of functional foods in Europe. Consensus Document.. British Journal of Nutrition, 81(4) : S1-S27.

[18] B.I.P.E.A. (1976) Bureau Interprofessionnel d'Etudes Analytiques. Recueil des Méthodes d'Analyses des Communautés Européennes,

[19] Danielie P (2001) Théorie et méthodes statistiques. Application agronomique. Les presses agronomiques de Gembloux. Editeur, Gembloux, Belgique; pp 463.

[20] Anonyme 1 (1983) Manuel d'Aviculture en zone tropicale, Ministère des Relations, Extérieures, Coopération et Développement. $2^{\text {éme }}$ Edition, Abidjan; 160-185.

[21] Pagot J, Bres P et QL Lecler (1983) Manuel d'Aviculture en zone tropicale, $2^{\text {ème }}$ de la série Manuel et Précis d'Elevage, réalisée par l'Institut d'Elevage et de Médecine vétérinaire des Pays tropicaux, publiée par le Ministère de la Coopération ISNB : 2 :11.084499-X.; pp 185.

[22] Bruijin GH (1971) A study on the cyanogenetic character of cassava. Meded. Lanbouwhogesch., Wageningen; (73): 1140

[23] Nartey F (1978) Studies on cassava, Manihot Utilissima pohl. Cyanogenesis: The biosynthesis, linamarin and lotaustralin in etiolated seedlings. Phytochemistry, (7): 1307-1312.

[24] Barbato GF, Cherry JA, Siegel PB and HP Van Krey (1980) Quantitative analysis of the feeding behaviour of four populations of chickens. Physiology and Behaviour, (25): 885-891. 
12 Beugré Grah Avit Maxwell et al:: Substitution of Wheat Bran by Cassava Flour in the Diet: Effect on the Growth of Chickens

[25] Anonyme 3 (1992) Le guide de l'agriculture en Côte d'Ivoire. Vol 4, éditeur, PRAT / EUROPA, Paris. 286 p.

[26] Anonyme 2 (1991) Mémento de l'agronome $4^{\text {ème }}$ édition, Edition CIRAD, Paris. p 1635.

[27] Hargis P S and M Van Elswyk (1993) Fatty acid modification of poultry products. World's Poultry. Science; (49): 251-264.

[28] Leskanich C O and RC Noble (1950) Manipulation of the n3 polyunsaturated fatty acid composition of avian egg and meat. World's Poultry Science, 1997; (53): 155-184 